\title{
豪雨災害を対象とした 保育所の業務継続のあり方
}

\author{
中野 晋 1 ・鳥庭 康代 $2 \cdot$ 武藤 裕則 $3 \cdot$ 宇野 宏司 4 - 金井 純子 5 \\ 1正会員＼cjkstart徳島大学教授＼cjkstart環境防災研究センター（テ770-8506 徳島市南常三島町2-1） \\ E-mail:nakano.susumu@tokushima-u.ac.jp \\ 2正会員＼cjkstart徳島大学技術補佐員＼cjkstart環境防災研究センター（†770-8506 徳島市南常三島町2-1） \\ E-mail:toriniwa@tokushima-u.ac.jp \\ 3正会員 徳島大学教授 大学院ソシオテクノサイエンス研究部（テ770-8506 徳島市南常三島町2-1） \\ E-mail:muto_yas@ce.tokushima-u.ac.jp \\ 4正会員 神戸市立工業高等専門学校准教授 都市工学科（干651-2194 神戸市西区学園東町8-3） \\ E-mail:uno@kobe-kosen.ac.jp \\ 5 正会員 徳島大学技術補佐員＼cjkstart環境防災研究センター（テ770-8506 徳島市南常三島町2-1） \\ E-mail:junko.kanai@tokushima-u.ac.jp
}

\begin{abstract}
養護と教育を一体的に実現することを責務とする保育所では家庭や学校以上に安全管理の高度化が求め られている. 近年，頻発する集中豪雨時のリスクマネジメントは保育所にとって喫緊の課題となっている. 2011年から2013年までに発生した豪雨による保育所の被災状況と保育を再開するまでの取り組みについて 保育所職員を対象としてインタビュー調查を実施した。インタビューで得られた内容を分析した結果, 豪 雨災害時の保育所での児童・職員の安全管理の点では避難を開始する水位の合理的決定や職員の緊急参集 時の安全確保で問題があることや保育業務を早期に再開するための業務継続計画の策定が進んでいない状 況など多くの課題が抽出された.
\end{abstract}

Key Words : disaster management,heavy rain, flood disaster, nursery school, BCP

\section{1. はじめに}

保育所の役割は保護者の協力の下に家庭教育の補完を 行うこと，養護と教育が一体となって，豊かな人間性を 持った子供を育成することなどである，これらの役割を 果たすため, 健康, 安全で情緒の安定した生活ができる 環境を整えることが保育所には期待されている（厚生労 働省・保育所保育指針 ${ }^{1}$ ) $)$ 。したがって，保育所では 家庭や幼・小・中学校などの教育機関以上に保健的環境 や安全の確保が必要であり, 自然災害に対しても高度な 安全管理の体制づくりが求められている.

東日本大震災では行方不明も含めて犠牲者が 18,000名 を超えた．保育所関係では岩手，宮城，福島の東北 3 県 で行方不明も含めて 114 名の園児が犠牲になっているが, その内 111 名は迎えに来た保護者に引き渡した後に津波 に巻き込まれるなど保育外で起こっており, 保育中に犠
牲になったのは 3 名のみであった2)。これはほとんどの 保育所で地震や火災を想定した避難訓練を定期的に実施 するなど地震に対するリスクマネジメントが行われてい たためであると推察される.

一方，毎年のように各地で頻発する豪雨災害に対する 安全管理も地震災害と同様, 避難支援の必要な園児を預 かる保育所にとって喫緊の課題である．最近でも 2011 年紀伊半島豪雨，2012年九州北部豪雨，2013年山口・ 島根豪雨，同京都・滋賀豪雨などでは，20～30年に 1度 またはそれ以上の深刻な被害が発生し，幼・小・中学校 などとともに，多くの保育所も床上浸水などの被害を受 けた，被災地の保育所では災害復旧に従事する保護者等 の要望もあり，自施設での早期復旧が難しい場合にも， 空施設を用いてできるだけ早く保育を再開することが期 待されており, 半年以上も他の保育施設で応急保育が行 われたケースもある。 
著者ら 32009年兵庫県佐用町豪雨や2011年紀伊半 島豪雨等の事例をもとに学校の防災管理の課題について まとめているが，豪雨による保育所の被苂と被災後の保 育業務の継続等について調査した事例はあまりなく，豪 雨災害を対象とした防災管理上の課題整理は進んでいな い. 地震や津波災害と同様，豪雨災害時の保育所の安全 管理と業務継続のあり方を探るため，最近，発生した豪 雨災害で被災した保育所を訪問し，被災状況と保育再開 までの取り組みに関してインタビュー調査を行った。

\section{2. 豪雨災害による保育所の被災と対応事例}

\section{（1）調査対象豪雨とインタビュ一調査の方法}

調査対象豪雨は2011年紀伊半島豪雨（2011年9月2日〜 4日），2012年九州北部豪雨（2012年7月12日），2013年 山口・島根豪雨（2013年7月28日），2013年京都・滋賀 豪雨（2013年9月15・16日）である.インタビューは紀 伊半島豪雨では那智勝浦町の井関保育所（2013年7月 4 日），勝浦認定こども園及び那智勝浦町福祉課（2013年 8月8日），九州北部豪雨では阿蘇市の内牧保育園（2012 年12月26日）, 山口・島根豪雨では萩市の須佐保育園, 田万川保育園, 田万川保育園小川分園, 萩市子育て支援 課を対象に2013年12月16・17日及び2014年4月28日にイン タビュー調査を行った。京都・滋賀豪雨では2014年2月 19日に福知山市のげん鬼保育園とわかば保育園でインタ ビュー調査を行った.

インタビューの対象は災害対応にあたつた所長や保育 土，保育所を指導する立場の自治体の担当者などで，施 設の被害と復旧状況，事前対策の内容，今回の被災経験 から得られた教訓と課題などについてお尋ねした。その 結果をもとに豪雨災害時に乳幼坚や職員の安全を確保す るための要点, 応急保育から通常保育に至るまでの保育 再開計画を作成する上での課題について考察する.

\section{（2）2011年紀伊半島豪雨についての結果}

四国から中国地方を縦断した台風 12 号の影響で, 2011 年 9 月 2 日から 9 月 4 日にかけ，紀伊半島では記録 的な豪雨となり，和歌山，三重，奈良の広い範囲で土砂 災害や浸水被害が発生し，行方不明者を合わせて全国で 98 名の犠牲者が生じた。 その中でも那智川流域では土 石流や河川氾濫により 27名が犠牲になっている4).

\section{a) 被災状況}

井関保育所は那智川の支流である金山谷川と本川との 合流点から下流約 $100 \mathrm{~m}$ の川沿いに位置する．金山谷沿 いの西山地区と金山地区で比較的規模の大きな崩壊があ り，金山谷川沿い発達した土石流が那智川本川に堆積し たため，下流の保育所には9月 3 日深夜から4日の未明

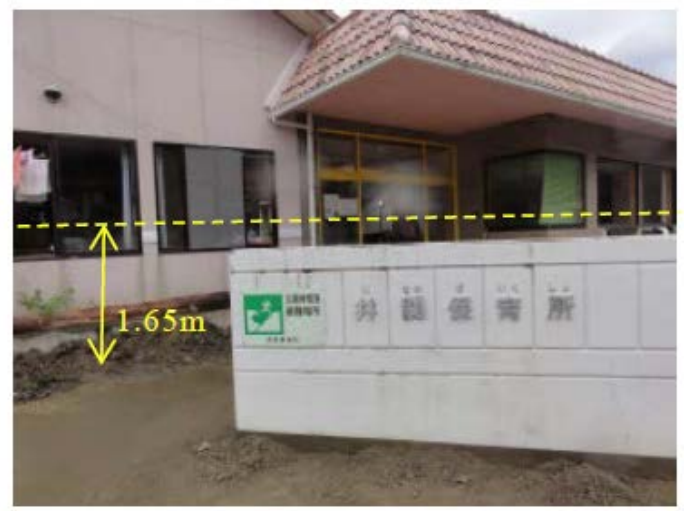

写真-1 井関保育所の浸水状況 (2011年9月 26 日, 著者撮影)

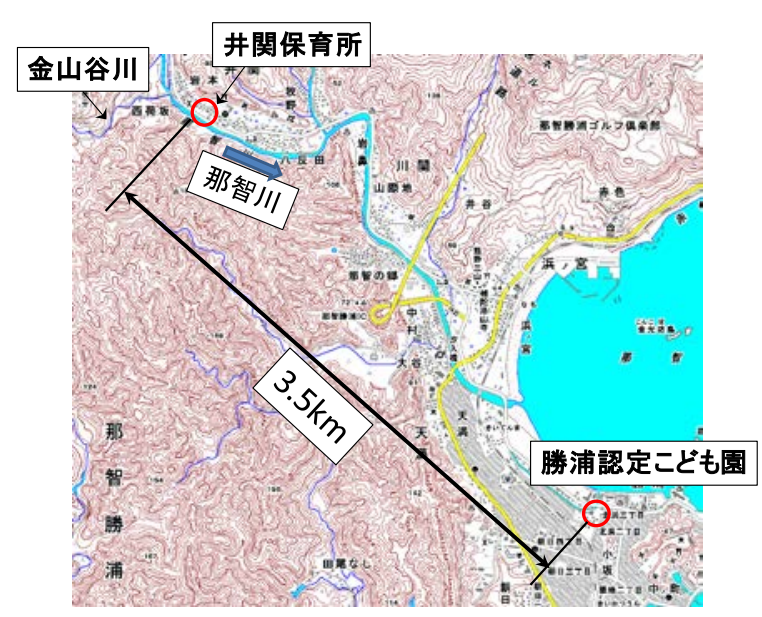

図-1 井関保育所と勝浦認定こども園の位置

にかけて，多量の土砂と汇濫水が押し寄せた．川側は壁 や空が破壊され，柱だけが残るような状況であった． 3 日 20 時 30 分に井関保育所に避難所が開設され，14名が 避難している. 河川汇濫により，4 日 1 時過ぎに浸水が 始まったため, 避難者は上流の市野々小学校に移動して いる.

写真-1 は2011年 9 月 26 日の現地調査時に山側から撮 影したもので, 路面から $1.65 \mathrm{~m}$ の高さ（床上浸水 $1.5 \mathrm{~m}$ ) に浸水痕跡が確認された。

平屋建ての井関保育所で $1.5 \mathrm{~m}$ の床上浸水被害を受け た中での保育再開は不可能であったため, 主管課である 那智勝浦町福祉課と協議した結果, 約 $3.5 \mathrm{~km}$ 離れた勝浦 認定こども園（図-1）で，9月 5 日から保育再開を行う こととなった. 一方, 井関保育所は 9 月 14 日から 10 月 10 日まで, 井関地区の現地災害対策本部が設置された ほか, 災害ボランティアセンター（井関サテライト， 10月 16 日まで）も設置された.

\section{b）緊急対応と保育再開}

井関保育所長は9月 4 日（日）早朝，保育所の被害状 態を確認するため, 膝まで水に浸かりながら, 消防団の 誘導ロープをたよりに浸水地区を横断し，園舎まで 40 
分かけて, 登園した. 被害状況を確認後, 那智勝浦町福 祉課に報告した．なお，町の災害対策マニュアルにおけ る参集基準では，参集が危険と判断される場合は確認に 行かないように記載されているが，安全か危険かの判断 は容易ではない.

所長からの連絡を受け，福祉課では 5 日から勝浦認定 こども園での応急保育の受け入れ調整を行ったほか,，電 話連絡で翌日からの保育の受け入れを各家庭に連絡した.

\section{c）応急保育の状況と課題}

応急保育を始めるに当たり，クラス担任から家庭の被 災状況と園坚の安否を電話で確認した。 子どもと直接電 話で話すことを通して，子どもの健康状態を確認すると ともに応急的なこころのケアを行った．なお，連絡がつ かないご家庭には，防災無線による放送や消防団の協力 を得て安否確認を行った。 町内で 0 歳児からの保育がこ の保育所だけであったため, 迅速な保育再開が必要であ り，発達段階に応じた環境が整っている勝浦認定こども 園での合同保育を実施することとなった。

この中で特に留意したことはこれまで通りの生活が送 れる環境づくりで, クラス担任を保育主任がサポートし て，子ども達の行動や情緒の変化を観察した.

一方で保護者や近隣の卒園生，井関保育所をべースと して活動していたボランティアグループの協力で園舎の 応急的な清掃を行い，2012年 3 月には最低限の修理を施 して手作り卒園式を挙行している. しかし, 園舎の改築 にはさらに 1 年を要し，2013年 3 月より，ようやく通常 保育が再開された。

勝浦認定こども園では 0 歳児からの乳幼児を受け入れ 体制が無かったため, 乳幼児用の保育環境を整える必要 があった. 乳幼児の一部は楽しく遊んでいるようでも自 分の名前の入ったものが無く，「借りている」というよ うな遠慮が見られた．多くの職員も園児同様，被災した 職員と支援している職員との受け止め方の違いに心苦し く感じており，乳幼児や保護者と同様，職員に対するこ ころのケアの必要性が重要視された．さらに，園舎の復 旧業務と応急保育を同時進行で行うため, 職員の負担は 大きかった.

\section{（3）2012年九州北部豪雨についての結果}

2012年7月11日から14日にかけて，本州付近に停滞し た梅雨前線に向かって南から湿った空気が流れ込み，西 日本から東日本にかけての広い範囲では記録的な豪雨と なった. 大分県, 熊本県, 福岡県など九州北部地域を中 心に死者・行方不明者が30名を超える災害となった．特 に白川上流域の阿蘇地方で記録的な降雨が発生し, 国土 交通省の坊中雨量観測所（熊本県阿蘇市黒川）において, 1 時間雨量 $124 \mathrm{~mm} ， 3$ 時間雨量 $315 \mathrm{~mm}$ を記録した ${ }^{5}$.

\section{a) 被災状況}

阿蘇市内牧周辺では7月12日6時過ぎから路面冠水が発 生しており，私立内牧保育園の近くの肥後銀行内牧支店 では7時半頃には黒川の上流右岸から汇濫した濁流が押 し寄せて来たと証言している（著者らのヒアリングによ

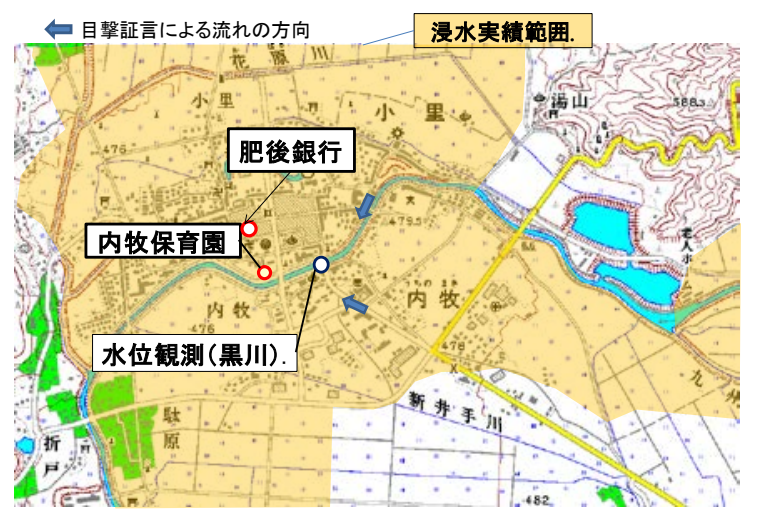

図-2 内牧保育園周辺の浸水状況

る）.内牧保育園では床上 $0.6 \mathrm{~m}$ 程度冠水し，パソコン, コピー機, 教室も含めた床暖房, 畳, 室外機等が被災し た。また，火山灰を多量に含んだ泥被害が深刻で，園庭 では泥の堆積により，1力月間使用できなかった。

\section{b) 緊急・応急対応と保育再開}

災害発生当時，道路冠水や通行止め等により，12日の 7時から16時まで園内に近づけない状況が続いた。緊急 連絡先の名簿が園内の事務所にしかなかったため, 園内 に入ることができた 16 時以降に，職員や園児らへの連絡 を開始した．職員数は24名で，連絡を受けた16名が参集 できた８名の職員は自宅が被災し，参集できなかった。

12日の16時から泥出し作業を行い，5日後の17 日から 園児たちを受け入れる体制が整ったが，衛生環境を整え るため, 日光や薬液での室内外の消毒と十分な換気を行 うため，実際に園児を受け入れるようになるまで，2週 間を要した。 また, その間も休園はなく, 応急保育とし て姉妹園での保育受け入れを行った。なお，この園は 1990年にも浸水被害を受けており，2012年4月に民営化 された際に水害保険に加入している．多額な復旧経費の 一部が保険により補填されており，復旧を速やかに行う 上でも有効であったようである.

\section{（4）2013年山ロ・島根豪雨についての結果}

2013年7月28日に山口県と島根県の県境付近を中心に 24時間351mm（萩市須佐）を超える集中豪雨があり，萩 市の須佐川や田万川で10時〜13時にかけて洪水汇濫に伴 う浸水被害が発生した．須佐川龍瀬橋水位局（萩市須佐） での最高水位は12時20分，田万川新市橋（萩市弥富下） での最高水位は11時20分に記録している6).

\section{a) 被災状況}

萩市立須佐保育園は汇濫した須佐川沿いに位置し，園 舎は約 $1.2 \mathrm{~m}$ 床上浸水した。萩市立田万川保育園小川分 
園は汇濫した田万川沿いに立地し，園舎は $0.6 \mathrm{~m}$ （床上 0.15m）の浸水被害を受けた。一方，萩市立田万川保育 園は高台にあるため，浸水被害がなかったため，須佐保 育園と田万川保育園小川分園の園児を受け入れて，合同 保育が行われた。

\section{b) 緊急対応と保育再開}

須佐保育園長は翌日の 7 月 29 日早朝に被害状況の把 握のため登園した．萩市内の自宅から保育園までの道路 が寸断されたため，島根県益田市を迂回して約 3 時間か けて自家用車で登園した，被害確認の後，主管課（萩市 保健福祉部子育て支援課）への報告，携帯電話を用いた 各家庭一安否確認が行われた. 田万川保育園小川分園長 は，自宅から危機感を感じながら山道を迂回し，被害発 生の当日に保育園に到着し, 主管課に被害報告を行って いる. 隣接する小川小学校（約 $1.4 \mathrm{~m}$ 浸水），役場支所, 近隣の家屋（1.37m浸水）も被災，情報が少ない中での 保護者一の安否確認と休園の連絡を携帯電話で実施して いる. 萩市役所と須佐保育園及び田万川保育園小川分園 はともに直線距離で $30 \mathrm{~km}$ 以上離れていることと市役所 周辺ではあまり雨が降らなかったこともあり，現場の災 害状況の把握は難しかったため, 園長の迅速な被害調査 と報告は重要であった。

須佐保育園では 30 日から避難所である須佐中学校の 一室で応急保育 (希望者, 給食なし) を再開, さらに 8 月 6 日からは被害のなかった田万川保育園の園舎の一部 を借りて保育（給食あり）を始めた，一方，田万川保育 園小川分園では園児数が少なく, 30 日から応急保育を 再開させたが，保護者からの申し出で家庭保育となった。 普段より田万川保育園（本園）との交流があったことか ら，本園にて 8 月 6 日より合同保育が実施された。

\section{c）応急保育の状況と課題}

合同保育を行うためにスクールバスによる遠距離の送 迎が必要である. 須佐保育園では, 通常より多くの園児 が利用するため, スクールバスでの乗車と降車時の安全 確保が課題となった．特に降車場所で安全に引き渡しが できるように引き渡し時のルールを決めて, 協力を要請 した．田万川保育園小川分園では停車場での送迎ができ ない家庭に対して，子育て支援センターの協力を得た。

合同保育に伴う保育環境の急変については, 須佐保育 園は保育室の一部を借り, クラス編成などは変更せずに 実施した。一方，田万川保育園小川分園は本園との合同 保育となり，本園に併せた年齢別クラスー保育体制を変 動，乳幼児は同年代のお友達が新たに出来た反面，今ま で一緒にいた友達がいなくなり不安を感じる幼児もいた また, 自分の名前の入ったペンやらくがき帳が無く, 乳 幼児のなかでも，遊びの中で「借りたもの」として使用 しているように見受けられた。施設を借りて応急保育を 実施した職員の中には「心苦しく思う」ものも多かった.

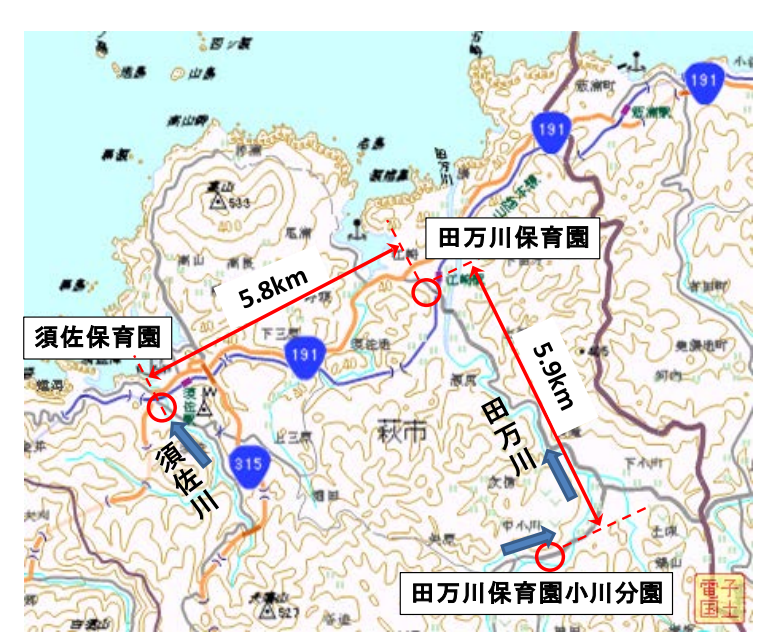

図-3 萩市立3保育園の位置困

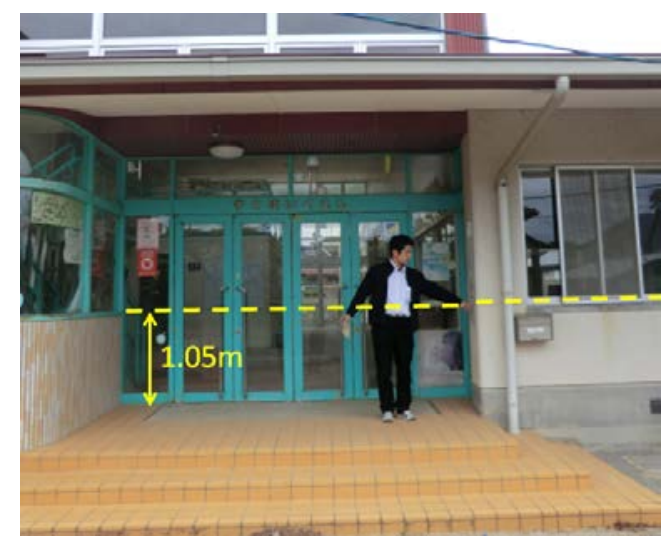

写真-2 須佐保育園浸水痕跡 (2013年 12 月 17 日撮影)

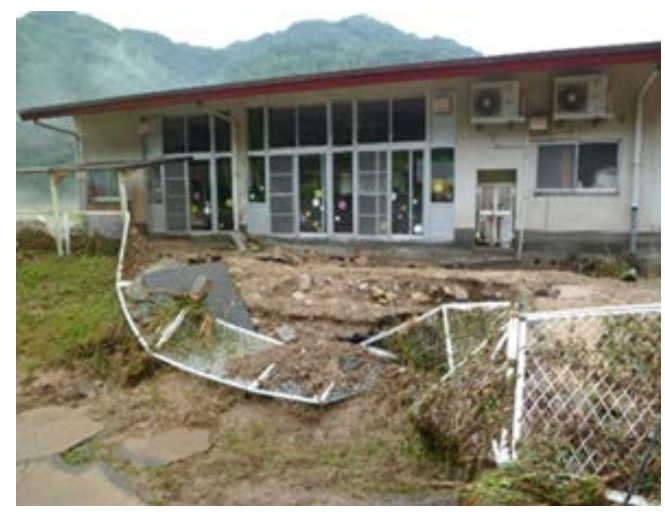

写真-3 田万川保育園小川分園の被災状況 (田万川保育園小川分園提供)

田万川保育園小川分園の場合, 現在地での修復工事が 行われた．園児が落ち着いて生活ができるよう園舎の内 装, 備品, 保育教材などを被災前とできる限り変えずに 整備された。修復工事は2013年12月末日に引き渡し， 2014年3月の卒園式を地元で行い，4月から再開された.

なお，保育再開にあたって，豪雨災害時の避難判断基 準をどうするかが決まっていないため, 不安に感じてい る. 分園周辺で水位観測局が設置されていないため, 避 難判断の参考にするための水位情報が入手しにくいこと 
が大きな課題となっている.

須佐保育園の場合は2014年4月に旧奈古高校須佐分校 跡地へ移転することが決まり，2016年4月を目途に新園 舎で保育を再開する予定である．2014年7月現在も引き 続き田万川保育園での一部を借り，保育を継続している.

\section{（5） 2013 年京都・滋賀豪雨についての結果}

2013年9月13日に発生した台風18号は16日8時に愛知県 豊橋市に上陸し，東日本を縦断した。この台風の影響で 15日から16日にかけて京都府や滋賀県で豪雨となり，16 日5時過ぎには，両県に初めて大雨特別警報が発表され る事態となった．綾部市，福知山市，舞鶴市などを流れ る由良川でも中下流で河川氾濫が生じ，福知山市戸田地 区や同大江地区では広範囲で床上浸水が発生した。由良 川の水位観測局での観測水位は戸田（福知山市字川北） で16日7時にT.P.24.64m，波美（福知山市大江町）で16日 11時にT.P.14.40mの最高水位を記録している。

由良川の汇濫に伴い，福知山市大江町の福知山市立げ 儿鬼保育園と福知山市戸田の私立わかば保育園が床上浸 水被害を受けた7)。

\section{a）被災状況}

大江町のげん鬼保育園は園舎周辺の路面で $1.2 \mathrm{~m}$ ，園庭 で0.3m，園舎内では0.2～0.25mの床上浸水であった（写 真-4）.しかし，幸いにも泥の堆積はほとんどなかった。

一方，戸田地区にある私立わかば保育園では16日早朝 には浸水が始まっており，保育園に近づけたのは17日朝 からである．戸田地区は図-5に示す工事中の堤防の未完 成部分からの汇濫と保育園の横を流れる用水路からの溢

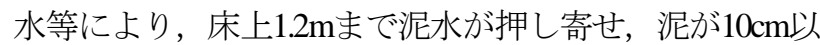
上堆積するような被害があった（写真-5）。

\section{b）緊急対応と保育再開}

げん鬼保育園では16日午後には園長がいち早く登園し， 園庭に流れ込んだ流木を濁水が引くのを利用して，外部 に撤去している．被災当日は職員2名，地元の調理員2名， 園長の5名の職員が山道を迂回して参集した。

被害状況を子育て支援課に連絡した後，保護者への一 斉メールで翌17日の休園を連絡したほか，家庭の浸水状 況と安否の確認を行った. 17日には職員，子育て支援課， 子育て支援センターなどの保育関係者の職員の協力を得 て，清掃，消毒作業を行った，床上浸水だったが，泥の 堆積がなかったことが幸いして，1日で殆ど保育再開が 可能な状態となったが，衛生上の消毒や部屋の乾燥をし つかり行うため，18日も1日休園措置をとり，19日から 保育再開した。 その際，損傷した乳幼児用の畳に代わっ て，他施設から保育マットを提供してもらい，乳幼児の 保育ができる環境を整えた。また，清掃と消毒には近隣 の大江高校の生徒や教員, 看護学校職員などもボランテ イアとして協力している.

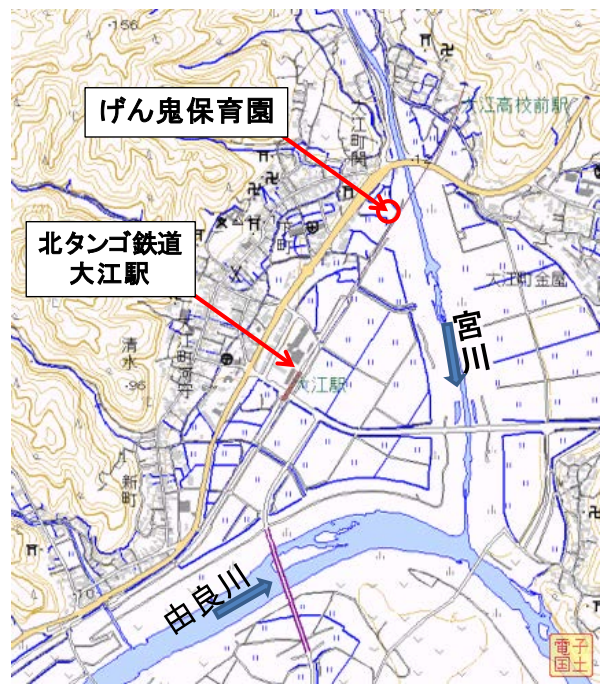

図-4 福知山市立げん鬼保育園の位置図

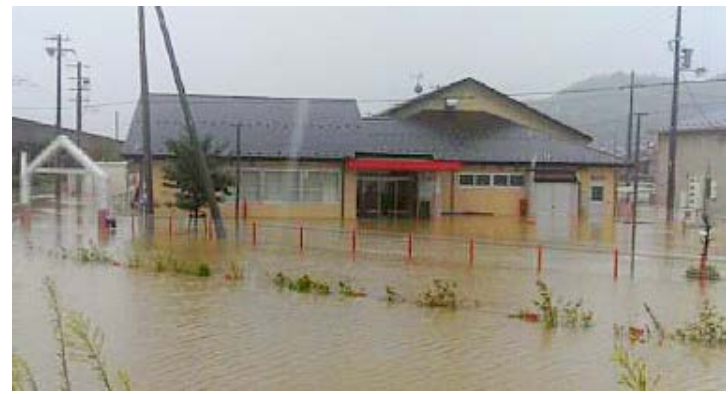

写真-4げん鬼保育園の浸水状況 (げん鬼保育園提供)

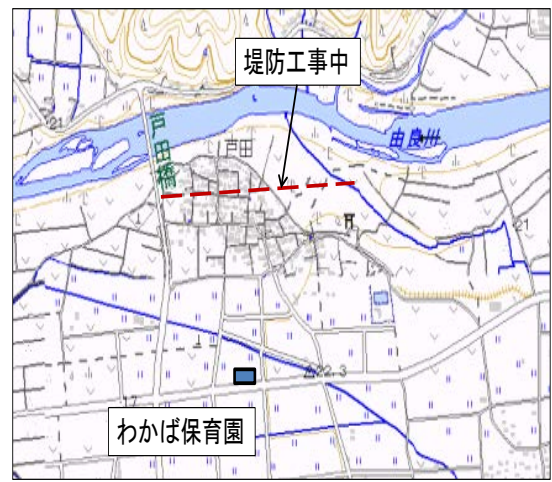

図-5 わかば保育園の位置図

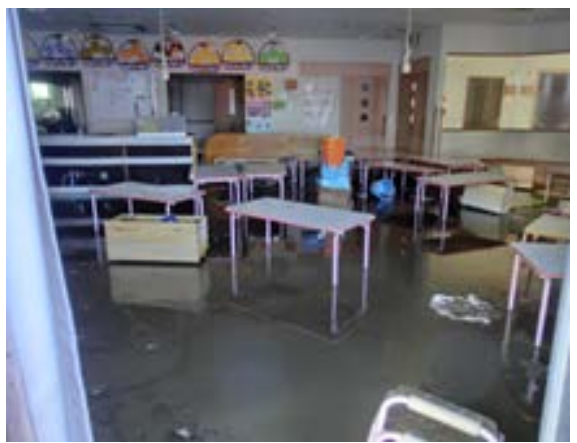

写真-5 わかば保育園舎内の浸水状況 (社会福祉法人・みつ夕福祉会提供) 
一方，わかば保育園では，泥の堆積が厚く，同施設で の早期再開は困難であったため，17日に急遽，福知山市 と協議して，休園中の幼稚園を借用して，19日から希望 登園の形（給食なし）で応急保育を始めている。また翌 週の月曜日（23日）には給食ありの保育も再開できた.

\section{c）応急保育の状況と課題}

わかば保育園では，借用した幼稚園に調理室がなかっ たため, 給食センターから乳幼児用の給食の提供を受け て, 給食ありの通常保育を再開することとなった. アレ ルギ一食の対応までは可能であったが, 咀嚼が困難な子 ぞもへの対応はできなかった．そうした乳幼児には 生命の維持を優先に考え, お弁当での対応となった.

保育環境としてはスペースが規定不足だったが，リズ ム室を利用して活動させて，3歳から5歳児を対象に異 年齢保育を行い, 様々な年齢の子どもと関われる状況を つくった. 一方， 0 ・ 1歳児，2歳览は，個別の部屋を用 意し，高年齢児と分けて安全な環境を整えた．災害時は, 保育環境が大きく変わる中，できるだけ普段の生活を維 持し, 乳幼児の情緒を落ち着かせることが重要であった また，被災した保育園と仮園舎の移動をスクールバスで 行う際，保護者への引き渡しが一齐に行われるため，駐 車場には送迎車が集中寸ることとなった．乳幼児の安全 を確保するために警備会社による駐車場の整理が必要と なった．また，被災した職員も多く，非常勤職員は休業 とし，正規職員と調理員のみで保育の業務と復旧作業を 同時に約 2 週間実施したことで，職員の負担が大きくな った. その後, 10月半ばから12月半ばまで業者による修 復工事を経て, 2014年1月から, 元の園で再開した.

\section{3. 災害に対する保育所のリスクマネジメント}

1.で述べたように保育所では家庭や幼稚園以上に保 健的環境や安全の確保が必要で, 自然災害に対しても高 度な安全管理の体制づくりが求められている. さらに保 護者が就労し，乳幼児に保育が必要となった時や入所家 庭が被災している場合には迅速に保育再開を行う必要が あるため，安全管理とともに災害前から災害後まで，シ 一ムレスに業務を継続することが期待されている. 表-1 は地震などの突発災害後の保育所の果たすべき役割をま とめたもので，発災から果たすべき役割は時間の経過に 伴って変化する．これらの役割を着実に果たすためには 災害時の業務継続計画 (BCP) を事前から作成し, 組織 として対応できるように職員一人ひとりが役割を認識し， いざという時に的確な判断と迅速な行動ができるように しておくことが大切である.

\section{（1）児童と職員の安全確保}

表-1 災害時の保育所の果たすべき役割

\begin{tabular}{|c|c|}
\hline ステージO & 児童と職員の安全管理 \\
\hline \multirow[t]{4}{*}{ おおよそ発災〜1日 } & O危機管理体制の確立 \\
\hline & ○安全確保と避難 \\
\hline & ○避難場所での安全管理 \\
\hline & ○保護者への引き渡し \\
\hline ステージ1 & 応急保育の開始 \\
\hline \multirow[t]{3}{*}{ おおよそ1日〜1週間 } & ○施設の被害確認 \\
\hline & ○施設の暫定復旧 \\
\hline & Oメンタルケア \\
\hline ステージ2 & 通常保育の再開 \\
\hline \multirow[t]{3}{*}{ おおよそ1週間〜1ヶ月 } & ○ライフラインの復旧 \\
\hline & ○職員の確保 \\
\hline & ○メンタルケア \\
\hline
\end{tabular}

今回調査した豪雨災害はいずれも休日に発生しており， 览童と職員を安全に避難させる上での問題は生じていな い.しかし，げん鬼保育園，小川分園，わかば保育園で は避難判断を行う基準が明確でないことに対して不安に 感じるとの意見があった．げん鬼保育園の場合，地元の 消防団員のアドバイスで園の近くの大雲橋での水位が 8mを超えたら避難をするように決めていたが，2004年 台風23号災害後に急ピッチで進んでいる河川改修の結果 流出特性に変化があったと判断して, より安全な基準と して, 園独自で避難を始める水位を $6 \mathrm{~m} に$ 変更している また，小川分園では近くに水位観測局がないため，参考 とすべき水位データがそもそもないという問題が生じて いる. そこで, 消防団などの協力者から早めに避難情報 を提供してもらうか，安全を確保しながら自ら河川水位 を目視等で観察し，事前に決めておいた水位に達寸ると 避難を始めるなどの対策が必要となる.

いずれにしろ，行政や専門家のアドバイスを得て，科 学的データに基づいた合理的な避難判断基準を自ら決定 し，それに基づく避難訓練を実施しておくことが大切で ある.

また，避難場所での安全管理に関しても今回の事例の 中では児童の避難の必要性がなかったため, 問題は顕在 化していないが，多くの保育所が平屋建てで，上層階へ の避難が難しいことを考えると, 近い場所に緊急避難場 所を確保するとともに，近隣の事業所などとの協力体制 を構築し, 避難時の支援者を確保することも重要な課題 である。

もう1点は災害発生後の職員参集の問題である. 井関 保育所を始め，ほとんどのケースで保育所長は浸水が継 続している最中に登園し, 被害確認などの作業を行って いる. 早期に被害確認を実施した結果, 井関保育所，小 川分園などで翌日または翌週月曜日から，別の施設を借 りて応急保育を開始することに成功している.しかし， こうした成功は所長等の安全の犠牲の上で成立している 点も見逃せない，たとえば，災害時は複数の職員で登園 
することや参集できない状態（参集対象外）にある場合 も事前に条件を業務継続計画で提示し，万が一を考えた 安全管理のルールを明確にしておくことが不可欠である。 東日本大震災で危険を顧みず，水門操作や避難誘導を行 った消防団などの防災関係者が多数殉職した教訓を無駄 にしてはならない.

\section{（2）保育業務の継続}

保育業務を早期に継続するためにはできるだけ早く被 害状況を確認し，自施設で再開寸るから゙うかについて， いち早く決断することが重要である，災害時の業務継続 を実現するための資源としては，「職員」「施設・設備」 「情報・通信」「ライフライン」「協力者」の5項目で あるが，保育業務についても上述の5項目が必須となる。

そこで, 以下では災害時に保育業務を継続する上で重 要な各資源の備えるべき要点を整理する.

\section{a) 職員}

施設管理者である所長等は自らの安全を確保した上で, 被害状況に応じて，業務継続方針を早期に決断する必要 がある. 今回の事例からもわかるように，災害時の保育 所での業務継続は応急保育と復旧作業を同時並行的に実 施する必要がある．他施設を借りて応急保育を開始寸る 場合にも通常保育と同様の保育環境を実現するための配 慮が必要である．一方，自施設で暫定復旧をした上で応 急保育をする場合にも衛生環境を保持するに十分な清掃 と消毒作業, 保育備品の再調達が不可久である.

また，通常保育と同様の環境を実現できた場合にも児 童や保護者を対象としたメンタルヘルスケアの実施など 応急保育の期間が長くなると職員の負担が大きくなる. 災害発生直後の緊急時や応急時においても疲労を蓄積さ せないために，災害発生直後に勤務計画表を作成して， 労務管理を適切に行うことが重要である. 職員本人はも ちろんのこと, 家族や自宅が被災した職員が出ることも 想定した上で表-2に示すような参集対象外の状態にある 職員を除いた業務継続方法を考えることも必要である.

b) 施設・設備

保育所では平屋建ての場合が多いため, 床上浸水が発 生すると保育室などの保育スペース, トイレ, 厨房, 受 電装置なども被災するため, 自施設で早期に再開させる ことは難しくなる，その場合には，他の施設の一部を保 育室として借りて再開するケースや他の保育所と合同で 応急保育を始めるケースが考えられる. 万が一の状況を 想定して, 相互協力を行うための事前協議を行っている とよい. また，20〜30 cm程度の浸水なら土囊や水囊に より床上浸水を防ぐことは可能であるため, 土囊等の備 蓄も有効である.

\section{C）情報・通信}

保育所は保護者が就労していることが多いため，急な

\section{表-2 職員参集基準（参集対象外） ${ }^{8)}$}

勤務時間外の災害発生時の職員参集基準

【参集対象外の状態にある職員】

(1) 職員自身もしくは家族が負傷している場合

(2) 自宅建物が被災し家族が危険な状態にある場合

(3) 小学生以下の家族の所在が不明でかつ連絡が取れない場合

(4) 小学生以下の家族が自宅にいて、他に保護する家族がいない場合

(5) 職員自身が外出先で帰宅難民になり出勤が不可能な場合

休園には対応できない保護者も多い。したがって，一斉 メールなどを用いて，休園や引き渡しに関する連絡を行 っている保育所も多くなっている. 保育所から保護者一 の一方通行の連絡だけではなく, SNSなどを用いた情報 の相互提供も検討すべき事項である.

\section{d) ライフライン}

保育所は養護の場であり, 給食の提供は安心感を維持 するためにおいても不可欠である. 保育所では0歳児か ら5歳児まで発達段階が大きく異なることとアレルギー 症を有する乳幼児も保育するため, 衛生的で安全な保育 環境を維持することが必要である. そのため, 水, 電気, ガス, 電話（携帯電話を含む）などの生活に必須なライ フラインの維持は極めて重要である. 特に, 電力はコン セントやキュービクルの高さを変えることで浸水を免れ る可能性があるため, 浸水予測に基づいた設備配置の変 更も重要な事前準備となる.

\section{e）協力者}

げん鬼保育園では子育て支援課, 他の保育施設の職員 などの協力により復旧活動が行われた. 災害ボランティ アなどの応援も必要であるが，災害時には保育所に理解 のある専門職員の協力が特に有益である. 近隣の保育所 間の協力と同様に保育の専門職員同士のネットワークを 構築し，いつでも協力できる体制を整えておくことも大 切である.

また，所長などの保育所の安全管理担当者からは防災 の専門家から適切な避難基準のアドバイスがあると心強 いとの指摘を受けた．行政の防災部局はもとより，地震， 津波, 風水害などについて専門的に研究を進める研究機 関の協力が望まれている.

\section{4. 保育所の業務継続計画策定に向けて}

保育所では市町村の主管課の指導を受けて，各施設ご とに災害対応マニュアルが作成されている，そのほとん どは, 災害時に児童を安全に避難させ，無事に保護者に 引き渡すまでの対応と夜間や休日に発災した場合に所長 や職員が緊急参集する手順に限られている. 特に, 昨年 の水防法の改正9に伴い, 避難に支援が必要な利用者が いる施設では避難確保計画の作成が必要となってきてい 
る。したがって，浸水危険性のある保育所では，児童が 安全に避難できるための避難確保計画の策定が必要であ り，その際，技術的な検討を踏まえた合理的な避難方法 が選定されることが望ましい.

すでに述べたように保育所は災害が発生した翌日にも 応急保育を開始することが期待されているため, 保育の 再開や継続に向けた業務継続計画の策定も重要となって いる．0歳児から5歳児までの発達段階の異なる览童ごと に必要な保育環境や保育体制を実現するための方法，被 災直後からの児童や保護者へのメンタルヘルスケアの方 法，応急保育時の職員の健康を考えた勤務体制，近隣の 施設や保育専門職員との連携方法などについてもできる だけ具体的に計画しておくことが望ましい.

その上で，業務継続計画の実効性を担保するための $\mathrm{BCP}$ 訓練の実施計画, 業務継続計画の見直し方法など PDCAサイクルに従って継続的に改善できる視点を盛り 込むことが重要である。

\section{5. おわりに}

今回の豪雨被害では幸いにも休日や夜間であったため, 児童を上層階や近くの避難場所に避難させるなどの対応 の必要性はなかった。しかし，保育所では就労支援のた めに，平日に加えて，土曜も保育をしているケースがほ とんどで，気象警報ではあまり休園とならないままた， 保護者の就労時間に合わせて，8時前から18時過ぎまで 保育をするため, 幼少中高などの学校と比べると子ども の帯在時間は長い場合がほとんどである. そうした点だ けから考えても，学校以上に児童に対する安全管理の徹 底が必要である.さらに，豪雨だけでなく，地震などの 自然災害の危険性が高まっており，避難対策に加えて， 応急保育から通常保育に至るまでの事業継続計画につい
ても事前に検討し，決めておくことがより重要となって いる.

謝辞 : 本研究を実施するに当たり, 被災から復旧活動を 行っているご多忙の中でインタビュ一調査にご協力いた だきました皆様に心より御礼申し上げます。また，調査 経費の一部は平成24年度文部科学省大学間連携共同教育 推進事業「四国防災・危機管理特別プログラム共同開設 による専門家の養成」の先進事例調査費を活用したこと を付記する.

\section{参考文献}

1) 厚生労働省 : 保育所保育指針, 平成20年告示, 35p., フレー ベル館, 2008.

2）河北新報 : 焦点/保育所、津波襲来で明暗/犠牲少なく、 毎月避難訓練で備え，2011年10月4日.

3) 中野晋・宇野宏司・照本清峰・高西春二 : 豪雨災害時の学 校防災管理の課題と対策，土木学会論文集（F6）安全問題, Vol.69, No.2, I_147-I_152, 2013.

4) 那智勝浦町 : 紀伊半島大水害 - 平成23年9月町を襲った台風 12号の記録, 346p., 2013.

5) 熊本県 : 平成24 年7 月12 日熊本広域大水害に係る被害状況 と熊本県の対応, pp.1-28, 2012.

6) 萩市 : 平成25年7月28日山口島根豪雨萩市総括（11月22日現 在暫定版），25p.，2013.（萩市提供資料）

7) 福知山市: 平成25年台風18号災害の記録, 64p., 2014.

8) 東京都社会福祉協議会 : 保育園における震災時対応ガイド ライン, 72p., 2014.

9) 国土交通省 : 水防法及び河川法の一部を改正する法律案に ついて, 平成25年4月5日発表, http://www.mlit.go.jp/common/ 000994078.pdf，（閲覧 : 2014年7月10日）

(2014. 7. 18 受付)

\title{
APPROPRIATE WAY OF BUSINESS CONTINUITY FOR NURSERY SCHOOL DUE TO HEAVY RAIN DISASTER
}

\author{
Susumu NAKANO, Yasuyo TORINIWA, Yasunori MUTO, Kohji UNO \\ and Junko KANAI
}

Advancement of the safety management is required in the nursery school which must carry out both nursing and education. The risk management in the heavy rain disaster which occurs frequently in recent years becomes the urgent problem. We were conducted the interview survey for staff of the nursery schools affected by a heavy rain disaster during 2011 and 2013 about the disaster situation of a nursery school and the response of post-disaster. From the analysis of the interviewed contents, the essential points of the safety management of children and nursing staff were summarized, and the problems for resuming nursing business quickly were shown. 